\title{
Quantitative analysis of the principal volatile compounds in oak wood by direct thermal desorption (DTD) and $\mathrm{GC} / \mathrm{MS}^{*}$
}

\author{
E. García-Romero ${ }^{1, * *}$, M.S. Pérez-Coello ${ }^{1}$, J. Sanz ${ }^{2}$ and M.D. Cabezudo ${ }^{1}$ \\ ${ }^{1}$ Food Science Laboratory, Faculty of Chemistry, Castilla-La Mancha University, 13071 Ciudad Real, Spain \\ ${ }^{2}$ Organic Chemistry Intitute, CSIC, Madrid, Spain
}

\begin{abstract}
This work proposes one method of quantifying the principal volatile compounds in oak wood using the direct thermal desorption (DTD) technique coupled with GC/MS. These compounds have a particular sensory importance in wines aged in oak wood barrels: furfural, trans and cis- $\beta$-methyl- $\gamma$-octalactones, eugenol, vanillin and syringaldehyde. The described method requires practically no sample handling and is precise and sensitive.
\end{abstract}

Key words. direct thermal desorption - volatile compounds - oak wood - wine ageing.

\section{Introduction}

During the wine ageing in wood barrels, a number of physico-chemical processes take place which affect the organoleptic characteristics of the product. Fruity aromas and the characteristic aromas of fermentation are replaced by others induced by the wood: vanilla, spices and oak [1,2].

The oak species most commonly used in barrel-making are: Quercus alba (found in a number of states in the US and also known as American oak), Quercus Petraea and Quercus robur, which are found in Europe, the most popular being French oak.

The sensory properties and chemical composition differences in the different types of oak wood used in cooperage $[3,4]$ are highly significant in commercial terms, and it is therefore important to know which ones yield most aroma compounds to the wine.

Most of the authors who have studied the composition of oak species have used hydro-alcoholic solutions, organic agents, wines and distillates which have been in contact with wood chips [5-7], and the subsequent analysis of the resulting extracts, either by GC (combined whit MS in many cases) or HPLC [8]. Of the numerous volatile compounds identified in wood extracts obtained in these ways, some are of particular sensory importance because of their low threshold values: furfural, oak lactones, vanillin and syringaldehyde $[9,10]$.

\section{Experimental}

Four oak wood samples were available, three samples of French oak (Quercus petraea from Allier, Vosges, and Central France forests) and one sample of American oak (Quercus alba). Samples were in the form of wood chips milled prior to analysis.

\section{Direct thermal desorption (DTD) conditions}

The ATD-400 is an automatic thermal desorption system developed by Perkin-Elmer for extracting volatile substances from solid samples for injection onto a chromatographic column.

An amount of $20 \mathrm{mg}$ of milled wood was placed together with internal standard in the desorption tube, plugged at both ends with silanized glass wool. The internal standard was $2 \mu \mathrm{L}$ of a solution of $\gamma$-caprolactone $(242 \mathrm{mg} / \mathrm{L})$. The desorption tube was heated to $180{ }^{\circ} \mathrm{C}$ for 30 minutes. The volatile substances were desorbed in a stream of helium at $50 \mathrm{~mL} / \mathrm{min}$ and collected in a cold trap $\left(-30^{\circ} \mathrm{C}\right)$ packed with Tenax. The trap was heated quickly to $300^{\circ} \mathrm{C}$ and the volatile substances transferred (split 1: 50) to the chromatographic column through a line heated to $225^{\circ} \mathrm{C}$.

In the studies with synthetic solutions, $3 \mu \mathrm{L}$ of a solution in dichloromethane at the concentration between $80-140 \mathrm{mg} / \mathrm{L}$ was injected into the empty desorption tube and subjected to the same DTD treatment as wood samples.

\section{Chromatographic conditions}

The apparatus was a Fisons model GC 8000 gas chromatograph connected to a model MD 800 mass detector. The column employed was a 25-m SE-54 (5\% diphenyl and 95\% dimethyl polysiloxane) column with an i.d. of $0.5 \mathrm{~mm}$ and $0.25 \mu \mathrm{m}$ of film thickness. The column temperature program was $60^{\circ} \mathrm{C}-(3 \mathrm{~min})-6^{\circ} \mathrm{C} / \mathrm{min}-250^{\circ} \mathrm{C}(40 \mathrm{~min})$. Transfer line temperature was $225^{\circ} \mathrm{C}$. Helium was the carrier gas. Column head pressure was 18.5 psi.

\section{Mass spectrum acquisition conditions (SIR mode)}

Ion production was by electron impact (EI) with an electron energy of $70 \mathrm{eV}$. Selected ion masses were: internal standard

* Presented at In Vino Analytica Scientia, Bordeaux, 12-14 June 1997.

** Cor respondence and reprints.

Received July 28, 1997; r revised November 05, 1997; accepted November 19, 1997. 
( $\gamma$-caprolactone): 85; furfural: 95 ; cis and trans $\beta$-methyl- $\gamma$ octalactones: 99; eugenol: 162; vanillin: 152; and syringaldehyde: 182 .

Ion collection time for all ions was $0.23 \mathrm{~s}$, and lag time between the acquisition of two consecutive ions was $0.020 \mathrm{~s}$.

\section{Results and discussion}

\section{Sensitivity of the detector}

With the mass spectrometer coupled to the gas chromatograph, it is possible to work in either SCAN mode (scanning a range of selected masses) or SIR mode (just registering the ions of interest). The latter is more specific and provides more sensitive detection. Synthetic solutions of the compounds to be quantified in the wood samples were analysed by DTD/GC/MS in SIR mode. The ratio signal/noise per pg of injected compound was between 10 to 30 .

\section{Method precision}

The proposed method precision was tested by performing nine consecutive DTD/GC/MS analyses of a synthetic solution. Table I shows the distribution of the values obtained and the results of the same synthetic solution injected directly in GC/MS.

Table I. Analysis of the synthetic solution by DTD (DTD/GC/MS) compared with direct injection (GC/MS).

\begin{tabular}{|c|c|c|c|c|c|c|}
\hline \multirow[b]{2}{*}{ COMPOUND } & \multicolumn{3}{|c|}{$G C / M S$} & \multicolumn{3}{|c|}{$D T D / G C / M S$} \\
\hline & $\begin{array}{l}\text { Mean } \\
\text { value }^{l}\end{array}$ & $S D$ & $\begin{array}{l}S D \\
(\%)\end{array}$ & $\begin{array}{l}\text { Mean } \\
\text { value }^{l}\end{array}$ & $S D$ & $\begin{array}{l}S D \\
(\%)\end{array}$ \\
\hline Furfural & 1.39 & 0.05 & 3.6 & 1.39 & 0.11 & 7.8 \\
\hline $\begin{array}{l}\text { trans- } \beta \text {-methyl- } \\
\gamma \text {-octalactone }\end{array}$ & 0.71 & 0.01 & 1.8 & 0.65 & 0.02 & 2.7 \\
\hline $\begin{array}{l}\text { cis- } \beta \text {-methyl- } \\
\gamma \text {-octalactone }\end{array}$ & 0.81 & 0.02 & 2.2 & 0.72 & 0.03 & 4.4 \\
\hline eugenol & 0.93 & 0.03 & 3.7 & 0.92 & 0.06 & 6.5 \\
\hline vanillin & 1.15 & 0.08 & 6.7 & 1.19 & 0.11 & 9.6 \\
\hline syringaldehyde & 1.36 & 0.10 & 7.3 & 1.33 & 0.14 & 10.5 \\
\hline
\end{tabular}

${ }^{1}$ Mean value of 9 injections (area of compound/area of Internal Standard).

The standard deviation values from analysis of direct injection in GC/MS were as expected, increasing as the volatility of the different compounds declined; the exception was furfural since its high volatility in the working conditions may have been the cause of some discrimination in the split injection. When DTD was coupled with the GC/MS system, precision decreased, although the values may be considered good enough due to the fact that precision of the entire process: extraction and analysis.

\section{Analysis of oak wood by DTD}

Four samples of oak wood of different provenances were analyzed by DTD/GC/MS; results are shown in table II. The
Table II. DTD/GC/MS analysis of four oak wood samples of different origin ( $\mu \mathrm{g}$ compound/g wood).

\begin{tabular}{|c|c|c|c|c|}
\hline \multirow[b]{2}{*}{ COMPOUND } & \multicolumn{4}{|c|}{$O A K$ WOOD } \\
\hline & U.S. & VOSGES & CENTRE & ALLIER \\
\hline Furfural & 88.1 & 173.4 & 97.8 & 38.0 \\
\hline $\begin{array}{l}\text { trans- } \beta \text {-methyl- } \\
\gamma \text {-octalactone }\end{array}$ & 0.31 & 1.81 & 3.79 & 0.39 \\
\hline $\begin{array}{l}\text { cis- } \beta \text {-methyl- } \\
\gamma \text {-octalactone }\end{array}$ & 3.24 & 8.85 & 4.94 & 2.18 \\
\hline eugenol & 0.08 & 0.17 & 0.47 & 0.08 \\
\hline vanillin & 4.06 & 8.98 & 7.73 & 4.69 \\
\hline syringaldehyde & 11.10 & 18.45 & 16.44 & 9.88 \\
\hline $\begin{array}{l}\text { cis-lactone/ } \\
\text { trans-lactone ratio }\end{array}$ & 10.45 & 4.89 & 1.30 & 5.59 \\
\hline
\end{tabular}

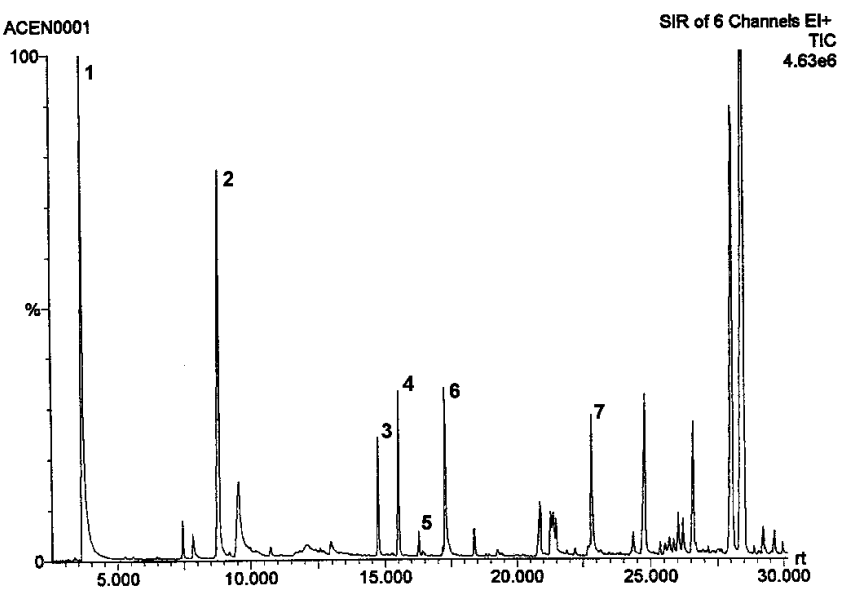

Fig. 1. Chromatogram of the volatile compounds in oak wood from Central France by DTD/GC/MS in SIR mode. 1: furfural, 2: $\gamma$-caprolactone (internal standard), 3: trans- $\beta$-methyl- $\gamma$-octalactone, 4: cis- $\beta$-methyl- $\gamma$-octalactone, 5: eugenol, 6 : vanillin and 7: syringaldehyde.

chromatogram from the Central France oak wood sample of the individual traces of the six ions is shown in figure 1.

The furfural concentration was much higher than it had been reported in the literature $(0.01-28 \mu \mathrm{g} / \mathrm{g})$ [11]. In the experimental conditions this result is probably due to the furfural of the wood matrix but also a produced furfural from the pentoses in the wood's hemicellulose [12] by thermal hydrolysis occuring at desorption temperature $\left(180^{\circ} \mathrm{C}\right)$.

Table II results show that wood from the three French forests contains higher concentrations than American oak of all of the studied compounds excepting the cis- $\beta$-methyl- $\gamma$ octalactone and syringaldehyde found in the Allier oak. On the other hand, there were differences among the three French oak samples of the same species: the Vosges oak contained more furfural, cis- $\beta$-methyl- $\gamma$-octalactone, vanillin and syringaldehyde than did oaks from Central France and from Allier.

Finally, differences were found in the concentration ratio 
of the oak lactone isomers in the different samples, which would support the proposal of this parameter as an indicator of oak wood origin $[7,13]$, however more samples should be analysed to raise statistical conclusions.

\section{Conclusions}

The proposed method of quantifying volatile components of oak wood by DTD/GC/MS is both precise and sensitive and has the advantages over classic extraction with organic solvents that it requires only a short analysis time and practically no sample handling.

This method is suitable for characterizing oak woods used in wines and distillates ageing, and for discriminating between woods from different geographic origins on the basis of their volatile composition.

\section{Acknowledgement}

This study was supported by project ALI95-0254-CO2-02 of Comision Interministerial de Ciencia y Tecnología.

\section{Références}

1. Aiken, J. W.; Noble, A. C. Am. J. Enol. Vitic, 1984, 35, 196199.
2. Piggott, J. R.; Conner, J. M.; Kelvin, J. L. Food flavors: gene ration, analysis and process; Charalambous, G. Ed.; Elsevier Sci. BV, 1995; pp 1695-1701.

3. Francis, I. L.; Sefton, M. A.; Williams, P. J. Am. J. Enol. Vitic, 1992, 43, 23-30.

4. Guichard, E.; Fournier, N.; Masson, G.; Puech, J. L. Am. J. Enol. Vitic, 1995, 46, 419-423.

5. Puech, J. L.; Moutounet, M. Lebensm-Wissn-Technol. 1992, 25, 350-352.

6. Chatonnet, P.; Boidron, J. N.; Dubourdieu, D.; Pons, M. J. Int. Sci. Vigne Vin, 1994, 28, 359-380.

7. Masson, G.; Guichard, E.; Fournier, N.; Puech, J. L. Am. J. Enol. Vitic, 1995, 46, 424-428.

8. Moutounet, M.; Rabier, P.; Puech, J. L.; Barillere, J. M. Sci. Aliments, 1989, 9, 35-51.

9. Boidron, J. N.; Chatonnet, P.; Pons, M. Conn. Vigne Vin, 1988, 22, 275-294.

10. Abbott, N.; Puech, J. L.; Bayonove, C.; Baumes, R. Am. J. Enol. Vitic, 1995, 46, 292-294.

11. Marco, J.; Artajona, J.; Larrechi, M. S.; Riux, F. Am. J. Enol. Vitic. 1994, 45, 192-200.

12. Nishimura, K.; Matsuyama; R. The science and technology of whiskies; Piggott J. R.; Sharp, R; Duncan, R. E. B. Eds.; Longman Scientific Technical, 1989, 235-263.

13. Waterhouse, A. L.; Towey, J. P. J. Agric Food Chem. 1994, 42, 1971-1974. 